\title{
EPIPHYTIC LICHENS AS INDICATORS OF ENVIRONMENTAL QUALITY AROUND A MUNICIPAL SOLID WASTE LANDFILL (C ITALY)
}

Luca Paoli ${ }^{1, *}$, Alice Grassi ${ }^{1}$, Andrea Vannini ${ }^{1}$, Ivana Maslaňáková ${ }^{2}$, Ivana Bil'ová2, Martin Bačkor ${ }^{2}$, 5 Adelmo Corsini ${ }^{3}$, Stefano Loppi ${ }^{1}$

${ }^{1}$ Department of Life Sciences, University of Siena, via P.A. Mattioli 4, I-53100, Siena, Italy;

${ }^{2}$ Department of Botany, Institute of Biology and Ecology, P.J. Šafárik University in Košice, Mánesova 23, SK-04001

Košice, Slovakia;

$10{ }^{3}$ Biologist, Pistoia, Italy

*corresponding author: Luca Paoli

Tel. (+39) 0577235408 - Fax (+39) 0577232896 - email: paoli4@unisi.it

\section{Abstract}

Epiphytic lichens have been been used as indicators of environmental quality around a municipal solid waste landfill in C Italy. An integrated approach, using the diversity of epiphytic lichens, as well as element bioaccumulation and physiological parameters in the lichen Flavoparmelia caperata (L.) Hale was applied along a transect from the facility. The results highlighted the

20 biological effects of air pollution around the landfill. The Index of Lichen Diversity (ILD) increased and the content of heavy metals $(\mathrm{Cr}, \mathrm{Cd}, \mathrm{Cu}, \mathrm{Fe}, \mathrm{Ni}$ and $\mathrm{Zn})$ decreased with distance from the landfill. Clear stress signals were observed in lichens growing in front of the facility, i.e. discoloration, necrosis, membrane lipid peroxidation, lower ergosterol content, higher dehydrogenase activity. Decreased photosynthetic efficiency, altered chlorophyll integrity and

25 production of secondary metabolites were also found. The results suggested that lichens can be profitably used as bioindicators of environmental quality around landfills.

Keywords: air pollution, biomonitoring, chlorophyll, heavy metals, Flavoparmelia caperata, Lichen Diversity Values, secondary metabolites

\section{Introduction}

There is a high public concern for the environmental and health impact related to waste management. Source reduction, reuse, recycling, composting, incineration and landfilling are part of

35 the integrated system for waste management. The European Commission considers landfilling as the least preferable option, which should be limited to the necessary minimum; however, it is still the main waste disposal method throughout Europe.

Recent legislation prescribes strict rules for waste disposal in landfills (European Union, Directive 2008/98/EC of the European Parliament and of the European Council of 19 November 2008).

40 Nevertheless, municipal solid waste (MSW) landfills may potentially contaminate fresh- and especially groundwater, soil, air and the biota. MSW landfills release a variety of air pollutants and among them landfill gas and particulate matter are particularly relevant. Emission of landfill gas poses environmental concern owing to the content of methane, carbon dioxide, nitrogen oxides and a mixture of contaminants, including volatile organic compounds (Chiriac et al., 2011; Sun et al.,

45 2013). Dumping activities are also a source of particulate matter, whose composition reflects the nature of the waste and the waste layer (terrain) used to stabilize the surface. Around landfill sites, enhanced concentrations of particulate-bound metals were found due to wind erosion, resuspension from the surface of the site, road surface dust and resuspension of deposited particulate matter on a road surface, refuse truck emissions e.g., exhausts, tire wear dust, brake wear dust (Chalvatzaki et al., 2010; 2014; Han et al., 2011). 
Recent environmental legislation prescribes objectives and rules for air quality to protect human health and the environment "paying particular attention to sensitive populations, and the environment as a whole, to improve the monitoring and assessment of air quality including the deposition of pollutants" (Directive 2008/50/EC of the European Parliament and of the Council of

5521 May 2008 on ambient air quality and cleaner air for Europe). Under the Air Quality Directive, biomonitoring of air pollution can contribute to the implementation of environmental policy on air quality and atmospheric pollution control, providing consistent data for environmental management (Pirintsos and Loppi, 2008). In this context, the use of lichens as bioindicators of environmental quality provides a special viewpoint on the atmospheric environment (Nimis et al., 2002).

60 Lichens are symbiotic organisms composed by green algae (or cyanobacteria) and fungi. Lichen metabolism depends on the mineral uptake from the atmosphere; therefore these organisms are effective in trapping trace elements from the surrounding environment. They grow very slowly, do not have stomata or cuticle regulating air exchanges and accumulate contaminants over the whole surface. Changes in the composition of lichen communities, trace element content and physiological

65 status are useful bioindicators, providing spatial and temporal evidence for trends in ambient pollution burdens (Loppi, 2014).

The diversity of epiphytic lichens proved to be a useful and robust indicator of air quality (Loppi et al., 2002). The concentrations of heavy metals in lichen thalli resulted correlated with their environmental levels (Bari et al., 2001; Sloof, 1995). In addition, several parameters (e.g.,

70 chlorophyll $a$ fluorescence emission, chlorophyll integrity, membrane lipid peroxidation, alteration of secondary metabolites, ergosterol content, dehydrogenase activity) have been introduced into experimental lichenology for the qualitative assessment of environmental stress (Bačkor, 2011). Only few lichen based studies reported on the biological effects of air pollution determined by different waste management strategies: waste incineration (Loppi et al., 1995, 2000; Paoli et al.,

75 2015; Tretiach et al., 2011); landfilling (Paoli et al., 2012), industrial composting (Paoli et al., 2014).

A comprehensive biomonitoring programme should integrate several methods distributed along the biomonitoring chain, allowing to detect exposure, threads and impacts also when waste management is concerned. Therefore, among these methods, changes in the diversity of epiphytic

80 lichens provide a useful method for monitoring the overall status of an ecosystem and the impacts of emissions; measuring the accumulation of airborne pollutants in lichen thalli (e.g., of heavy metals) can be used to assess spatial and temporal exposure; measuring physiological responses allows detecting early effects of ongoing processes and threads, before their consequences are apparent at higher levels (Bealey et al., 2008; Paoli et al., 2015).

85 In the present study, epiphytic lichens have been used as indicators of environmental quality around a MSW landfill, addressing specific questions: does the landfill influences i) the diversity of epiphytic lichens, (ii) the bioaccumulation of selected heavy metals, and (iii) the physiological status of lichens?

\section{Material and Methods}

\subsection{Study area}

The investigated landfill $\left(43^{\circ} 52^{\prime} 52^{\prime \prime} \mathrm{N}, 10^{\circ} 53^{\prime} 21^{\prime \prime} \mathrm{E}\right.$, ca. $60 \mathrm{~m}$ asl) is located in Tuscany, C Italy. Operating since 1996, it extends over an area of $160,000 \mathrm{~m}^{2}$ and actually it is foreseen to last until

952027 , when the overall volume will be $3,010,000 \mathrm{~m}^{3}$. The authorized daily capacity is 420 tons. The disposed material consists of municipal solid, hazardous and non hazardous wastes and the material for landfill cover. Wastes may include scraps of paper, plastics and metals, packing, spent tires, textile products, building materials, ashes from municipal solid waste incinerators, polluted terrain from environment reclamation, etc.

100 The landfill site is located over an impermeable natural clay layer; bottom and side boundaries may 
vary according to the period of cultivation. They generally include protective layers, such as a compact clay layer $(100 \mathrm{~cm})$, geotextile membranes, gravel $(50 \mathrm{~cm})$, geomembranes, non-woven fabric $\left(1200 \mathrm{~g} / \mathrm{m}^{2}\right)$, pulper products $(50 \mathrm{~cm})$. Landfill covers consist of a waste layer (terrain) to stabilize the surface, drainage systems, compact clay $(20 \mathrm{~cm})$, soil bentonite and a vegetative soil

105 layer (up to $100 \mathrm{~cm}$ ). A grassy mantle and/or reafforestation with local vegetation complete the recovery of the site after closing of each parcel. Systems for leachate treatment, and for gas recovery, collection and treatment, are in operation and landfill gas is used to support energy needs. Atmospheric concentrations of several pollutants of environmental concern in the vicinity of the landfill were available through instrumental monitoring (source Pistoiambiente). Referring to the

110 period corresponding to our study (spring 2012 - spring 2013), values were within the following ranges (hourly concentrations, $\left.\mu \mathrm{g} / \mathrm{Nm}^{3}\right)$ : As (0.14-0.73), $\mathrm{Cd}(0.14-0.16), \mathrm{Cr}(12-29), \mathrm{Cu}(0.6-8.4)$, $\mathrm{Ni}(6.4-18.4), \mathrm{Pb}(3.3-4.8), \mathrm{V}(0.18-0.25)$ and $\mathrm{HF}(0.10-0.35), \mathrm{HCl}(0-6.3), \mathrm{NO}_{\mathrm{x}}(25-82), \mathrm{SO}_{\mathrm{x}}$ (0.1-6.3).

The landfill is surrounded to the N,W and $\mathrm{S}$ by a vegetation belt dominated by Quercus cerris and

$115 Q$. pubescens. Vineyards, olive plantations and woodlands characterize the hilly surroundings, while to the E lowland, several plant nurseries and inhabited areas prevail. The climate of the area is intermediate between sub-oceanic and sub-Mediterranean, with mean annual rainfall over $1300 \mathrm{~mm}$ and mean annual temperature of $14.1^{\circ} \mathrm{C}$.

\section{$120 \quad 2.2$ Experimental design}

To assess possible biological effects caused by the presence of the landfill, sampling sites were classified into three groups according to the distance from the landfill: 1) sites directly facing the landfill; 2) sites located at about $200 \mathrm{~m}$ from the landfill; 3) sites located at about $1500 \mathrm{~m}$ from the landfill.

125 The above distances were selected based on previous studies (Paoli et al., 2012): in particular, sites of group 2) correspond to the outer margin of the vegetation belt surrounding the landfill, which roughly ranges up to $200 \mathrm{~m}$. The distance of $1500 \mathrm{~m}$ corresponds to sites with negligible impact. For each group, three sampling sites were investigated in the period May 2012 - May 2013 for lichen diversity as well as element bioaccumulation and physiological status in native lichen thalli

130 of the species Flavoparmelia caperata (L.) Hale. Sampling sites are represented by circular plots of $60 \mathrm{~m}$ diameter. Since the sampling sites at about $1500 \mathrm{~m}$ from the landfill belongs to the regular monitoring network of $500 \mathrm{~m} \times 500 \mathrm{~m}$ installed in the surrounding territory, for the homogeneity of data distribution, the plot of $60 \mathrm{~m}$ diameter has been selected within this level (see next paragraph).

The diversity of epiphytic lichens and the accumulation of selected elements were investigated as

135 part of prescriptions implemented to improve the environmental performance of the facility and enhance health protection (Eco-Management and Audit Scheme, EMAS).

\subsection{Assessment of the lichen diversity}

The diversity of epiphytic lichens was measured according to the standardized protocol of Asta et

140 al. (2002). An Index of Lichen Diversity (ILD, also named LDV "Lichen Diversity Value" see e.g. CEN standard EN 16413 "Ambient air - Biomonitoring with lichens - Assessing epiphytic lichen diversity) was computed using a sampling grid consisting of four $50 \times 10 \mathrm{~cm}^{2}$ ladders, each divided into five $10 \times 10 \mathrm{~cm}^{2}$ units. The grid was positioned systematically on the $\mathrm{N}, \mathrm{E}, \mathrm{S}$ and $\mathrm{W}$ cardinal sides of the bole of each tree, at a height of $1 \mathrm{~m}$ above ground. The ILD of the tree corresponded to

145 the sum of frequencies of epiphytic lichens in the grid and the ILD of each monitoring site was the arithmetic mean of the ILD measured for each sampled tree. Trees for epiphytic lichen sampling (Q. cerris and $Q$. pubescens) were deemed suitable if well lit, with girth $>60 \mathrm{~cm}$, trunk near straight, not damaged and without parts with $>25 \%$ cover of bryophytes. Three trees were sampled in each sampling site. In case of identification problems during field sampling, specimens were collected

150 and identified later in the laboratory. Nomenclature follows the online database Italic (Nimis and 
Martellos, 2008).

\subsection{Bioaccumulation of trace elements}

The bioaccumulation of selected elements in native lichens was investigated according to Bargagli and Nimis (2002). Thalli of the foliose lichen $F$. caperata were collected for element analysis. The species $F$. caperata was chosen because of its wide distribution in the study area and because it had been already used in bioaccumulation studies (Loppi et al., 2004; Paoli et al., 2012). At each sampling site, 10-30 thalli growing on the bole of 3-10 Q. cerris or Q. pubescens trees were harvested from all cardinal exposures, at 1-2 m from ground. Tree boles were deemed suitable for

160 lichen harvesting if almost straight, not damaged and without parts with $>25 \%$ cover of bryophytes. In the laboratory, samples were carefully cleaned under a stereoscopic microscope to remove extraneous material deposited onto the surface, such as moss samples, bark pieces and soil particles. Only the peripheral part of the thalli (up to $5 \mathrm{~mm}$ from lobe tips) was selected for the analysis; in $F$. caperata this part roughly corresponds to the last year of growth and can be easily separated from

165 the bark, being distinguishable by a paler colour and absence of rhizinae. Concentrations of selected elements of toxicological concern (As, $\mathrm{Cd}, \mathrm{Cr}, \mathrm{Ni}, \mathrm{Pb}, \mathrm{V}, \mathrm{Zn}$ ) and $\mathrm{Fe}$ (being associated to soil contamination of the samples) were determined by ICP-MS (Perkin Elmer - Sciex, Elan 6100) as reported in Paoli et al. (2012) and expressed on a dry weight basis $(\mu \mathrm{g} / \mathrm{g} \mathrm{dw})$. Analytical quality was checked by analysing the Standard Reference Material IAEA-336 'lichen'. Precision of analysis

170 was estimated by the coefficient of variation of 4 replicates and was found to be within $10 \%$ for all elements. Three replicates were measured at each site.

\subsection{Physiological parameters}

The following parameters were used for the assessment of the physiological status of the lichens:

175 chlorophyll integrity, photosynthetic efficiency, membrane lipid peroxidation, viability, ergosterol content and secondary metabolites.

\subsubsection{Chlorophyll integrity}

Photosynthetic pigments were measured as described in Pisani et al. (2007). Two extraction cycles, $18045 \mathrm{~min}$ each, were run in a warm bath $\left(65^{\circ} \mathrm{C}\right)$, using $5 \mathrm{~mL}$ of DMSO. Absorbance of the extracts was measured using a UV-visible spectrophotometer (Agilent 8453). Chlorophyll integrity was expressed by the ratio between the absorbance at 435 and $415 \mathrm{~nm}\left(\mathrm{OD}_{435} / \mathrm{OD}_{415}\right)$. A decrease of this ratio reflects chlorophyll $a$ degradation to phaeophytin $a$ (Garty et al., 2000). Five replicates were measured at each site.

\subsubsection{Photosynthetic efficiency}

The photosynthetic efficiency of the samples was assessed in terms of chlorophyll (Chl) $a$ fluorescence emission, that was analysed by the classical physiological indicator $\mathrm{F}_{\mathrm{V}} / \mathrm{F}_{\mathrm{M}}$, representing the potential quantum yield of primary photochemistry, where $F_{v}=\left(F_{M}-F_{0}\right)$ is the

190 variable fluorescence and $\mathrm{F}_{0}$ and $\mathrm{F}_{\mathrm{M}}$ are minimum and maximum $\mathrm{Chl} a$ fluorescence. Samples were lightened $1 \mathrm{sec}$ with a saturating $3000 \mu \mathrm{mol} / \mathrm{m}^{2} \mathrm{~s}$ light pulse and fluorescence emission was recorded for $1 \mathrm{sec}$. Samples were measured with a Plant Efficiency Analyzer (Handy PEA, Hansatech Ltd, Norfolk, UK). Ten replicates were measured at each site.

\section{2.5.3 Membrane lipid peroxidation}

Membrane lipid peroxidation was estimated using the thiobarbituric acid reactive substances (TBARS) assay, as reported in Pisani et al. (2011). TBARS are a decomposition product of polyunsaturated fatty acids which are produced during peroxidation of membrane lipids (Mittler, 2002). Their content increases upon exposure of lichen thalli to high concentrations of toxic elements (Bačkor et al., 2010; Pisani et al., 2011).Five replicates were measured at each site, results 
were expressed as $\mu \mathrm{mol} / \mathrm{g}(\mathrm{dw})$.

\subsubsection{Sample viability}

Triphenyltetrazolium chloride (TTC) reduction to triphenylformazan (TPF) is a good indicator of dehydrogenase activity (dark respiration) and was used to assess sample viability according to Bačkor and Fahselt (2005). Results were expressed as absorbance units/g (dw). Five replicates were measured at each site.

\subsubsection{Ergosterol content}

210 Ergosterol content in lichens is sensitive to the exposure to heavy metals, which likely reduces the integrity of cell membranes of the mycobiont. Samples $(100 \mathrm{mg})$ were measured as indicated in Dahlman et al. (2002). Ergosterol absorption at $280 \mathrm{~nm}$ was measured with a UV detector (Ecom LCD 2084). As ergosterol is sensitive to light, all steps were conducted almost in the dark. Three replicates were measured at each site.

\subsubsection{Secondary metabolites}

Secondary metabolites (caperatic and usnic acid) were measured as indicated by Bačkor et al. (2011). Three replicates were measured at each site.

\section{2.6 Data interpretation and statistical analysis}

Significance of differences $(\mathrm{P}<0.05)$ concerning total ILD, element accumulation and physiological parameters was checked by ANOVA, using the HSD Tukey test for post-hoc comparisons. The ILD values were interpreted in terms of air pollution according to the following scale (Paoli and Loppi, 2008): $0=$ very high (lichen desert), $1-40=$ high, $41-80=$ moderate, $81-120=$ low, $>120=$

225 negligible. Metal concentrations were interpreted in terms of air pollution based on a scale (Table 1) desumed from Bargagli and Nimis (2002). The Spearman correlation test was used to investigate correlations between lichen diversity, physiological parameters and heavy metals. Prior to the analysis, data were transformed on a $0(\min )-1(\max )$ scale.

\section{3. Results}

\subsection{Lichen diversity (ILD)}

The lichen diversity values and the list of the species recorded along with their average frequency, are summarized in Table 2. The Index of Lichen Diversity (ILD) significantly increased moving

235 from the landfill to the group of sites at $1500 \mathrm{~m}$ from the landfill $(F=23.89 P=0.000)$. ILD values indicated conditions of high to moderate air pollution in front of the landfill, moderate to low air pollution at $200 \mathrm{~m}$, and low to negligible air pollution at $1500 \mathrm{~m}$. Thirty-seven epiphytic lichens were recorded. The average number of species per sampled tree was 9 at the landfill, 11 at $200 \mathrm{~m}$, 16 at $1500 \mathrm{~m}$. The highest contribution to lichen frequencies were determined by crustose, tolerant

240 species (e.g., Candelariella xanthostigma, Lepraria sp.). The lichen vegetation along the transect was dominated by mesophilous and acidophilous or subneutrophilous species, while only few species were nitrophilous (Table 2). The frequency of the widespread foliose lichen $F$. caperata clearly decreased approaching the landfill, while species typically occurring in relatively undisturbed areas (Catillaria nigroclavata, Collema subflaccidum, Phlyctis argena, Physcia clementei, Physconia perisidiosa, P. servitii) were present only at 200 and $1500 \mathrm{~m}$.

\subsection{Heavy metals}

A notable statistically significant decrease in the accumulation of trace elements in the lichen $F$. caperata was observed along with distance from the landfill (Table 3). Values measured in samples collected in front of the landfill indicated high air pollution for $\mathrm{Cr}$ and $\mathrm{Ni}$, moderate air pollution for 
$\mathrm{Cd}, \mathrm{Cu}, \mathrm{Fe}$ and $\mathrm{Zn}$, low air pollution for $\mathrm{As}$ and $\mathrm{Pb}$. Values measured in samples collected at $200 \mathrm{~m}$ indicated moderate air pollution for $\mathrm{Ni}$, low air pollution for $\mathrm{Cd}, \mathrm{Cr}, \mathrm{Cu}, \mathrm{Fe}$ and $\mathrm{Zn}$, very low air pollution for $\mathrm{As}$ and $\mathrm{Pb}$. Values for all elements but $\mathrm{Ni}$ measured in samples collected at $1500 \mathrm{~m}$ indicated a condition of very low air pollution; moderate air pollution emerged for $\mathrm{Ni}$.

\subsection{Physiological parameters}

The investigated physiological parameters allowed detecting stress symptoms in the lichens collected in front of the landfill (Table 4). Lower chlorophyll integrity $\left(\mathrm{OD}_{435 / 415}\right)$ and higher dehydrogenase activity were found at the sites directly facing the landfill. Peroxidated membrane lipids (TBARS) and lowered ergosterol content were found up to $200 \mathrm{~m}$ from the landfill. Trends were not so clear for secondary metabolites, but overall caperatic acid decreased and usnic acid increased approaching the landfill. Photosynthetic efficiency $\left(\mathrm{F}_{\mathrm{v}} / \mathrm{F}_{\mathrm{M}}\right)$ was not affected by the landfill, although lower values were occasionally measured in lichen thalli facing the landfill. Observations carried out on $F$. caperata revealed signs of discoloration and necrosis in samples

265 collected in front of the cultivated area. No sign of damage was observed at other sites. In addition, a notable increase of the number of dying thalli on the bark of Quercus trees in front of a new parcel under cultivation was observed. These thalli are also widely parasitized by lichenicolous fungi.

\subsection{Correlations between ILD, physiological parameters and heavy metals}

270 Spearman rank correlation coefficients between the investigated parameters are shown in Table 5 . In general, the lichen diversity (ILD) was negatively correlated with the content of heavy metals and TBARS and positively with chlorophyll integrity and the content of secondary metabolites. The content of heavy metals (but Ni) was positively correlated with that of TBARs and negatively with chlorophyll integrity. A negative correlation emerged between all investigated elements and usnic

275 acid and between the content of $\mathrm{Fe}, \mathrm{Cd}, \mathrm{Zn}, \mathrm{As}, \mathrm{Pb}$ and caperatic acid. In addition, $\mathrm{Fe}, \mathrm{Cd}, \mathrm{Zn}, \mathrm{As}$, $\mathrm{Pb}$ were positively correlated with dehydrogenase activity. Concerning physiological parameters, $\mathrm{OD}_{435 / 415}$ was positively correlated with the content of ergosterol and secondary metabolites, caperatic acid negatively with TBARS and usnic acid negatively with dehydrogenase activity. Chlorophyll $a$ fluorescence emission was not significantly correlated with any of the other 280 parameters.

\section{Discussion}

The fact that the lichen communities (diversity, number of species, presence of sensitive lichens) steadily indicated an improvement of environmental conditions, from high-moderate pollution to

285 low-negligible effects according to the distance from the source, suggested that the dumping activities were the cause of the worsening of conditions compared with the surrounding area. This evidence agrees with a condition of environmental alteration limited to the sites directly facing the landfill, as reported by Paoli et al. (2012). In addition, the lichen diversity was negatively correlated with the content of heavy metals, whose depositions decreased with distance from the landfill.

290 Recent studies including a biodiversity assessment reported the use of higher plants and lichens as bioindicators around waste management facilities (Kotovicová et al., 2011; Paoli et al., 2014; Vaverková et al., 2012). For instance, vascular plants (and few lichen species) were used as biological indicators in Czech Republic to assess the potential impact of landfill sites on the surrounding soil and the atmospheric environment, based on presence of species, biomass

295 production and the and occurrence of stress symptoms (Kotovicová et al., 2011; Vaverková et al., 2012). Data suggested a limited impact around landfill sites operating in compliance with the most modern and strictest requirements and standards. An assessment of lichen diversity around a composting plant of organic waste in $\mathrm{C}$ Italy revealed a local eutrophication due to atmospheric $\mathrm{NH}_{3}$ depositions, which enhanced the diffusion of nitrophilous species (Paoli et al., 2014).

300 Airborne particulate matter arising from landfilling operations may be highly enriched in heavy 
metals depending on the nature of the materials and the resuspension from the surface of the site (Chalvatzaki et al., 2014). A study carried out around a MSW landfill near Mexico City revealed that the resuspended surface dust from the landfill heavily influenced the composition of airborne particulate in the surrounding area (Vega et al., 2001). A study carried out around a MSW 305 composting site in Crete (Greece) revealed dust emissions by erosion of the piles and subsequent depositions with maximum concentrations at a distance of $25-75 \mathrm{~m}$ downwind of the piles in the direction of prevailing wind. Concentrations above the $24 \mathrm{~h}$ limit for the protection of human health were occasionally measured at distances up to $275 \mathrm{~m}$ from the source (Chalvatzaki et al., 2012). Compared with the surrounding environment, the elemental content of our lichens around the

310 landfill was enriched in $\mathrm{Cd}, \mathrm{Cr}, \mathrm{Cu}, \mathrm{Fe}, \mathrm{Ni}$ and $\mathrm{Zn}$. Consistently, the analysis of airborne emissions from a landfill in the $\mathrm{UK}$, indicated $\mathrm{Cr}, \mathrm{Fe}, \mathrm{Ni}, \mathrm{Pb}$ and $\mathrm{Zn}$ as the main components of the particulate matter around the site (Koshy et al., 2009). Similarly, a study carried out with the lichen Pseudevernia furfuracea near Rome around the largest European MSW landfill showed a significant bioaccumulation of $\mathrm{As}, \mathrm{Cd}, \mathrm{Cr}, \mathrm{Cu}, \mathrm{Ni}, \mathrm{Pb}$ and $\mathrm{Zn}$ (Protano et al., 2014). In our study, the 315 heavy metal content decreased by $37-71 \%$ moving from sites directly facing the landfill to sites 200 $\mathrm{m}$ away. In this process it is noteworthy the buffering role of the vegetation belt dominated by oak trees surrounding the landfill in limiting the spreading of airborne particulate matter. Green belts are known sinks for air pollutants, including gases and particulate matter, and trees are able to act as filters through leaf adsorption, deposition of aerosols and particulate on leaf surfaces and fallout on 320 leeward side of vegetation belts (Smith, 1990).

Heavy metals originating from landfill operations likely affected the physiological status of $F$. caperata, reducing chlorophyll integrity and increasing membrane lipid peroxidation and dark respiration. In addition, higher chlorophyll degradation and membrane lipid peroxidation were correlated with sites facing the landfill characterized by lower lichen diversity. The fact that in 325 lichens chlorophyll degradation is correlated with the accumulation of heavy metals is well documented (Garty et al., 2000). Moreover, the toxic effect of $\mathrm{Cd}, \mathrm{Cr}, \mathrm{Cu}$ and $\mathrm{Ni}$ on chlorophyll integrity and TBARS content has been specifically tested in lichens (Bačkor et al., 2009; 2010; Unal et al., 2010). Ergosterol, a sterol component of fungal cell membranes, can be affected by exposure to heavy metals around a waste landfill, as suggested by our results. Ergosterol is 330 considered a good indicator of mycobiont viability, as its content correlates with the amount of metabolically active fungal cells (Ekblad et al., 1998) and laboratory treatments of lichen thalli with heavy metals (i.e. $\mathrm{Cd}, \mathrm{Cu}$ and $\mathrm{Ni}$ ) significantly reduced ergosterol content according to the dose (Bačkor et al., 2009; 2010). This is in agreement with a higher content of TBARS found in the thalli facing the landfill. Our samples increased the rate of respiration close to the landfill, as suggested 335 by the level of dehydrogenase respiratory activity. This parameter is often taken as indicator of viability upon exposure to several stressors, including heavy metals (Bačkor and Fahselt, 2005), so that a decreased activity of respiratory dehydrogenases is negatively correlated with high doses of elements (Bačkor, 2011; Pisani et al., 2011). However, within a certain degree, their increase could be stress-induced and linked to the activity of other enzymes with antioxidant activity involved in 340 the detoxification of heavy metals.

The negative correlations between the content of heavy metals and the content of usnic and caperatic acid suggest that heavy metals affected the production of secondary lichen metabolites. It is noteworthy that usnic acid, a yellow cortical pigment exhibiting antibiotic effects, protects the lichen against bacteria and fungi and caperatic acid, a medullary compound, may have a similar 345 role. Therefore, it is highly likely that $F$. caperata samples close to the landfill are parasitized by lichenicolous fungi since at these sites they have decreased protections against these parasites. Interestingly, the ratio between cortical and medullary secondary metabolites was found to increase in lichen samples transplanted in proximity of a local soil contamination source by waste dumping in Slovakia (Lackovičová et al., 2013). Similarly, due to the decrease of medullary caperatic acid, 350 this ratio also increased in our samples, being 0.13 at a distance of 1500 and $200 \mathrm{~m}$ and 0.60 at the 
landfill. All the above evidences suggest that an integrated use of lichen based methods, i.e. methods with a stronger link to source attribution (e.g., bioaccumulation), methods reflecting ongoing processes (e.g., physiological responses) and their environmental effects (e.g., biodiversity assessments), could contribute to the definition of environmental quality based on the biological effects of different waste management practices on sensitive components of the ecosystems (Paoli et al., 2015).

\section{Conclusions}

This study showed that lichens can profitably be used as bioindicators of the biological effects of air pollution around a municipal solid waste landfill and that they depict the status of environmental quality around such facilities. Lichens showed an impoverished flora and an increased accumulation of heavy metals at sites facing the landfill. In addition, also the physiological status was affected: lower chlorophyll integrity and higher membrane lipid peroxidation, as well as alteration of secondary metabolites were found in the investigated $F$. caperata samples. However, these results

365 also highlighted that the atmospheric impact caused by the landfill is spatially limited, also due to the buffering action of a green oak belt surrounding the landfill, suggesting that successful and sustainable waste management may be associated with satisfactory environmental quality.

\section{References}

Asta, J., Erhardt, W., Ferretti, M., Fornasier, F., Kirschbaum, U., Nimis, P.L., Purvis, O.W., Pirintsos, S., Scheidegger, C., Van Haluwyn, C., Wirth, V., 2002. Mapping lichen diversity as an indicator of environmental quality. In: Nimis, P.L., Scheidegger, C., Wolseley, P.A. (Eds.), Monitoring with Lichens - Monitoring Lichens. Kluwer Academic Publishers, pp. 273-279.

Bačkor, M., 2011. Lichens and heavy metals: toxicity and tolerance. Pavol Jozef Šafárik University in Košice.

Bačkor, M., Kováčik, J., Dzubaj, A., Bačkorová, M., 2009. Physiological comparison of copper toxicity in the lichens Peltigera rufescens (Weis) Humb. and Cladina arbuscula subsp. mitis (Sandst.) Ruoss. Plant Growth Regul. 58, 279-286.

380 Bačkor, M., Kováčik, J., Piovár, J., Pisani, T., Loppi, S., 2010. Physiological aspects of cadmium and nickel toxicity in the lichens Peltigera rufescens and Cladina arbuscula subsp. mitis. Water Air Soil Pollut. 207, 253-262.

Bačkor, M., Péli, E. R., Vantová, I., 2011. Copper tolerance in the macrolichens Cladonia furcata and Cladina arbuscula subsp. mitis is constitutive rather than inducible. Chemosphere 85, 106-113.

Bačkor, M., Fahselt, D. 2005. Tetrazolium reduction as an indicator of environmental stress in lichens and isolated bionts. Environ Exp Bot 53, 125-133.

Bargagli, R., Nimis, P.L., 2002. Guidelines for the use of epiphytic lichens as biomonitors of atmospheric deposition of trace elements. In: Nimis, P.L., Scheidegger, C., Wolseley, P.A. (Eds.), Monitoring with Lichens - Monitoring Lichens. Kluwer Academic Publishers, pp. 295-299.

Bari, A., Rosso, A., Minciardi, M.R., Troiani, F., Piervittori, R., 2001. Analysis of heavy metals in atmospheric particulates in relation to their bioaccumulation in explanted Pseudevernia furfuracea thalli. Environ Monit Assess 69, 205-220.

Bealey, W.J., Long, S., Spurgeon, D.J., Leith, I., Cape, J.N., 2008. Review and implementation study of biomonitoring for assessment of air quality outcomes. Science Report SC030175/SR2. Environment Agency, Bristol, pp. 1-170.

Chalvatzaki, E., Aleksandropoulou, V., Lazaridis, M., 2014. A case study of landfill workers exposure and dose to particulate matter-bound metals. Water Air Soil Pollut 225, 1782. 
Chalvatzaki, E., Aleksandropoulou, V., Glytsos, T., Lazaridis, M., 2012. The effect of dust emissions from open storage piles to particle ambient concentration and human exposure. Waste Manage, 32, 2456-2468.

Chalvatzaki, E., Kopanakis, I., Kontaksakis, M., Glytsos, T., Kalogerakis, N., Lazaridis, M. 2010. Measurements of particulate matter concentrations at a landfill site (Crete, Greece). Waste Manage, 11, 2058-2064.

Chiriac, R., De Araujos Morais, J., Carre, J., Bayard, R., Chovelon, J.M., Gourdon, R., 2011. Study of the VOC emissions from a municipal solid waste storage pilot-scale cell: Comparison with biogases from municipal waste landfill site. Waste Manage 31, 2294-2301.

410 Dahlman, L, Zetherström, M., Sundberg, B., Näsholm, T., Palmqvist, K., 2002. Measuring ergosterol and chitin in lichens. In: Kranner, I., Beckett, R., Varma, A. (Eds.). Protocols in Lichenology: Culturing. Biochemistry. Ecophysiology and Use in Biomonitoring. SpringerVerlag, pp. 348-362.

415 living biomass in ectomycorrhizae. New Phytol 138, 143-149.

Garty, J., Weissman, L., Tamir, O., Beer, S., Cohen, Y., Karnieli, A., Orlovsky, L., 2000. Comparison of five physiological parameters to assess the vitality of the lichen Ramalina lacera exposed to air pollution. Physiol Plantarum 109, 410-418.

Han, S., Youn, J.S., Jung, Y.W., 2011. Characterization of $\mathrm{PM}_{10}$ and $\mathrm{PM}_{2.5}$ source profiles for resuspended road dust collected using mobile sampling methodology. Atmos Environ 45, 3343-3351.

Koshy, L., Jones, T., BéruBé, K., 2009. Characterization and bioreactivity of respirable airborne particles from a municipal landfill. Biomarkers 14, 49-53.

Kotovicová, J., Toman, F., Vaverková, M., Stejskal, B., 2011. Evaluation of waste landfills impact on the environment with the use of bioindicators. Pol J Environ Stud, 20, 371-377.

Lackovičová, A., Guttová, A., Bačkor, M., Pišut P., Pišut, I., 2013. Response of Evernia prunastri to urban environmental conditions in Central Europe after the decrease of air pollution. Lichenologist 45, 89-100.

Loppi, S., 2014. Lichens as sentinels for air pollution at remote alpine areas (Italy). Environ Sci Poll Res 41, 2563-2571.

Loppi, S., Frati, F., Paoli, L., Bigagli, V., Rosetti, C., Bruscoli, C., Corsini, A., 2004. Biodiversity of epiphytic lichens and heavy metal contents of Flavoparmelia caperata thalli as indicators of temporal variations of air pollution in the town of Montecatini Terme (central Italy). Sci Tot Environ 326, 113-122.

435 Loppi, S., Ivanov, D., Boccardi, R., 2002. Biodiversity of epiphytic lichens and air pollution in the town of Siena (central Italy). Environ Pollut 116, 123-128.

Loppi, S., Putortì, E., De Dominicis, V., Barbaro, A., 1995. Lichens as bioindicators of air quality near a municipal solid waste incineration plant in central Italy. Allionia 33, 121-129.

Loppi, S., Putortì, E., Pirintsos, S.A., De Dominicis, V., 2000. Accumulation of heavy metals in epiphytic lichens near a municipal solid waste incinerator (central Italy). Environ Monit Assess 61, 361-371.

Mittler, R., 2002. Oxidative stress, antioxidants and stress tolerance. Trends Plant Sci 7, 405-410.

Nimis, P.L., Scheidegger, C., Wolseley, P.A. (Eds.), 2002. Monitoring with Lichens - Monitoring Lichens. NATO Science Series. Kluwer Academic Publishers, Dordrecht, Netherlands, pp. 408.

Nimis, P.L., Martellos, S., 2008. ITALIC - the Information System on Italian Lichens. Version 4.0. IN4.0/1. University of Trieste, Dept. of Biology. http://dbiodbs.univ.trieste.it/.

Paoli, L, Benesperi, R., Proietti Pannunzi, D., Corsini, A., Loppi, S., 2014. Biological effects of ammonia released from a composting plant assessed with lichens. Environ Sci Pollut Res 21, $5861-5872$. 
Paoli, L., Corsini, A., Bigagli, V., Vannini, J., Bruscoli, C., Loppi, S., 2012. Long-term biological monitoring of environmental quality around a solid waste landfill assessed with lichens. Environ Pollut 161, 70-75.

Paoli, L., Munzi, S., Guttová, A., Sardella, G., Loppi, S., 2015. Lichens as suitable indicators of the biological effects of atmospheric pollutants around a municipal solid waste incinerator (S Italy) Ecol Indic 52, 362-370.

Paoli, L., Loppi, S., 2008. A biological method to monitor early effects of the air pollution caused by the industrial exploitation of geothermal energy. Environ Pollut 155, 383-388.

Pirintsos, S.A., Loppi, S., 2008. Biomonitoring atmospheric pollution: the challenge of times in environmental policy on air quality. Environ Pollut 151, 269-271.

Pisani, T., Munzi, S., Paoli, L., Bačkor, M. , Loppi, S., 2011. Physiological effects of arsenic in the lichen Xanthoria parietina (L.) Th. Fr. Chemosphere 82, 963-969.

Pisani, T., Paoli, L., Gaggi, C., Pirintsos, S.A., Loppi, S., 2007. Effects of high temperature on epiphytic lichens: issues for consideration in a changing climate scenario. Plant Biosyst 141, $1-6$.

Protano, C., Guidotti, M., Owczarek, M., Fantozzi. L., Blasi, G., Vitali, M., 2014. Polycyclic aromatic hydrocarbons and metals in transplanted lichen (Pseudevernia furfuracea) at sites adjacent to a solid waste landfill in Central Italy. Arch Environ Contam Toxicol 66, 471-481.

Sloof, J.E., 1995. Lichens as quantitative biomonitors for atmospheric trace-element deposition using transplant. Atmos Environ 29, 11-20.

Smith, W.H., 1990. Air Pollution and Forests: Interaction between air contaminants and forest ecosystems. Second Edition, Springer-Verlag, New York.

Sun, Y., Wang, Y.-N., Sun, X., Wu, H., Zhang, H., 2013. Production characteristics of $\mathrm{N}_{2} \mathrm{O}$ during stabilization of municipal solid waste in an intermittent aerated semi-aerobic bioreactor

475 landfill. Waste Manage 33, 2729-2736.

Tretiach, M., Candotto Carniel, F., Loppi, S., Carniel, A., Bortolussi, A., Mazzilis, D., Del Bianco, C., 2011. Lichen transplants as a suitable tool to identify mercury pollution from waste incinerator: a case study from NE Italy. Environ Monit Assess 175, 589-600.

Unal, D., Isik, N.O., Sukatar, A., 2010. Effects of chromium VI stress on photosynthesis, chlorophyll integrity, cell viability, and proline accumulation in lichen Ramalina farinacea. Russ J Plant Physiol 57, 664-669.

Vaverková, M., Toman, F., Kotovicová, J., 2012. Research into the occurrence of some plant species as indicators of landfill impact on the environment. Pol J Environ Stud 21, 755-762.

Vega, E., Mugica, V., Reyes, E., Sanchez, G., Chow, J.C., Watson, J.G., 2001. Chemical composition of fugitive dust emitters in Mexico City. Atmos Environ 35, 4033-4039. 
Table 1. Scale for the interpretation of trace element concentrations in lichens ( $\mu \mathrm{g} / \mathrm{g} \mathrm{dw}$ ) desumed after Bargagli and Nimis (2002).

\begin{tabular}{lcccccccc}
\hline air pollution & $\mathbf{A s}$ & $\mathbf{C d}$ & $\mathbf{C r}$ & $\mathbf{C u}$ & $\mathbf{F e}$ & $\mathbf{N i}$ & $\mathbf{P b}$ & $\mathbf{Z n}$ \\
\hline very low & $<0.4$ & $<0.3$ & $<2$ & $<9$ & $<400$ & $<1.5$ & $<10$ & $<35$ \\
low & 1.2 & 0.6 & 4 & 15 & 800 & 3.0 & 25 & 65 \\
moderate & 1.9 & 1.2 & 6 & 25 & 1200 & 5.0 & 55 & 95 \\
high & 2.5 & 2.1 & 13 & 40 & 1600 & 7.0 & 95 & 135 \\
very high & $>2.5$ & $>2.1$ & $>13$ & $>40$ & $>1600$ & $>7$ & $>95$ & $>135$ \\
\hline
\end{tabular}


Table 2. Index of Lichen Diversity (ILD) and list of lichen species. ILD was interpreted in terms of air pollution according to paragraph 2.6. Significant differences between sites $(P<0.05)$ are indicated by a different letter. $\operatorname{Pr}=$ percentage of relevés where each species has been recorded, Fr $=$ frequency expressed as percentage. Nomenclature of the species follows Nimis and Martellos (2008); ${ }^{n}$ nitrophilous lichen.

\begin{tabular}{|c|c|c|c|c|c|c|}
\hline & \multicolumn{2}{|c|}{ landfill } & \multicolumn{2}{|c|}{$200 \mathrm{~m}$} & \multicolumn{2}{|c|}{$1500 \mathrm{~m}$} \\
\hline Index of Lichen Diversity & \multicolumn{2}{|c|}{$45 \pm 12^{c}$} & \multicolumn{2}{|c|}{$72 \pm 13^{b}$} & \multicolumn{2}{|c|}{$113 \pm 28^{\mathrm{a}}$} \\
\hline (impact of air pollution) & (high & erate) & $(\bmod$ & low) & $($ low & gible) \\
\hline Lichen species & Pr & Fr & Pr & $\mathbf{F r}$ & Pr & $\mathbf{F r}$ \\
\hline Lepraria sp. & 89 & 61 & 86 & 74 & 50 & 32 \\
\hline Candelariella reflexa ${ }^{n}$ & 78 & 53 & 58 & 39 & 67 & 53 \\
\hline Flavoparmelia caperata & 42 & 16 & 69 & 51 & 75 & 50 \\
\hline Parmelia sulcata & 28 & 6 & 50 & 21 & 17 & 3 \\
\hline Cladonia coniocraea & 22 & 13 & 36 & 21 & 8 & 2 \\
\hline Leprocaulon microscopicum & 22 & 14 & 19 & 9 & & \\
\hline Physcia adscendens ${ }^{n}$ & 22 & 8 & 3 & 3 & 92 & 57 \\
\hline
\end{tabular}


Punctelia borreri

$\begin{array}{cccccc}19 & 8 & 39 & 17 & 75 & 62 \\ 17 & 8 & 56 & 27 & & \\ 17 & 8 & 22 & 9 & 50 & 45 \\ 17 & 3 & 22 & 7 & 8 & 2 \\ 11 & 7 & 14 & 7 & 58 & 45 \\ 8 & 3 & 56 & 42 & 8 & 5 \\ 8 & 4 & 11 & 4 & 33 & 15 \\ 8 & 2 & 3 & 1 & 50 & 48 \\ 8 & 5 & & & & \\ 3 & 1 & 14 & 6 & 25 & 5 \\ 3 & 1 & 6 & 2 & 8 & 2 \\ 3 & 1 & 6 & 1 & & \\ 3 & 1 & & & 17 & 3\end{array}$

Normandina pulchella

Parmotrema perlatum

Flavoparmelia soredians

Melanelixia fuliginosa

Hyperphyscia adglutinata ${ }^{n}$

Candelaria concolor ${ }^{n}$

Candelariella xanthostigma

Pertusaria albescens

Evernia prunastri

Ramalina farinacea

Xanthoria parietina ${ }^{n}$

Aplotomma turgida

Physcia tenella

Phlyctis argena

Lecanora symmicta

Lecidella elaeochroma"

Parmelina tiliacea

Amandinea punctatan

Catillaria nigroclavata

Lecanora carpinea ${ }^{n}$

Physconia servitii

Lecanora chlarotera ${ }^{n}$

Physconia grisea ssp.grisea ${ }^{n}$

Collema subflaccidum

Physconia perisidiosa

Phaeophyscia orbicularis ${ }^{n}$

$\begin{array}{cccc}11 & 4 & & \\ 8 & 4 & 42 & 27 \\ 8 & 3 & & \\ 6 & 2 & 33 & 18 \\ 6 & 2 & 33 & 17 \\ 6 & 4 & 8 & 5\end{array}$

Physcia clementei 
Table 3. Content of trace elements $(\mu \mathrm{g} / \mathrm{g})$ in the lichen Flavoparmelia caperata as a function of distance from the landfill. Heavy metals were interpreted in terms of air pollution according to the intervals given in Table 1.

\begin{tabular}{|c|c|c|c|c|}
\hline Elements & landfill & $200 \mathrm{~m}$ & $1500 \mathrm{~m}$ & ANOVA \\
\hline As & $\begin{array}{c}0.49 \pm 0.10^{\mathrm{a}} \\
\text { low }\end{array}$ & $\begin{array}{c}0.31 \pm 0.05^{\mathrm{b}} \\
\text { very low }\end{array}$ & $\begin{array}{c}0.18 \pm 0.031^{c} \\
\text { very low }\end{array}$ & $F=29.12 P=0.000$ \\
\hline $\mathrm{Cd}$ & $\begin{array}{l}0.62 \pm 0.01^{\mathrm{a}} \\
\text { moderate }\end{array}$ & $\begin{array}{c}0.37 \pm 0.01^{\mathrm{b}} \\
\text { low }\end{array}$ & $\begin{array}{c}0.24 \pm 0.03^{\mathrm{c}} \\
\text { very low }\end{array}$ & $F=32.35 P=0.000$ \\
\hline $\mathrm{Cr}$ & $\begin{array}{l}7.5 \pm 4.2^{\mathrm{a}} \\
\text { high }\end{array}$ & $\begin{array}{l}2.2 \pm 0.3^{\mathrm{b}} \\
\text { low }\end{array}$ & $\begin{array}{l}1.3 \pm 0.2^{\mathrm{b}} \\
\text { very low }\end{array}$ & $F=13.32 P=0.003$ \\
\hline $\mathrm{Cu}$ & $\begin{array}{l}17.8 \pm 6.8^{\mathrm{a}} \\
\text { moderate }\end{array}$ & $\begin{array}{l}9.9 \pm 1.0^{\mathrm{b}} \\
\text { low }\end{array}$ & $\begin{array}{l}6.6 \pm 0.1^{\mathrm{b}} \\
\text { very low }\end{array}$ & $F=13.08 P=0.000$ \\
\hline $\mathrm{Fe}$ & $\begin{array}{l}1092 \pm 413^{\mathrm{a}} \\
\text { moderate }\end{array}$ & $\begin{array}{c}525 \pm 20^{\mathrm{b}} \\
\text { low }\end{array}$ & $\begin{array}{l}275 \pm 7^{\mathrm{b}} \\
\text { very low }\end{array}$ & $F=18.67 P=0.000$ \\
\hline $\mathrm{Ni}$ & $\begin{array}{l}6.0 \pm 1.6^{\mathrm{a}} \\
\text { high }\end{array}$ & $\begin{array}{l}3.6 \pm 0.3^{b} \\
\text { moderate }\end{array}$ & $\begin{array}{l}4.4 \pm 0.2^{\mathrm{ab}} \\
\text { moderate }\end{array}$ & $F=13.82 P=0.000$ \\
\hline $\mathrm{Pb}$ & $\begin{array}{c}22.9 \pm 12.6^{\mathrm{a}} \\
\text { low }\end{array}$ & $\begin{array}{l}6.9 \pm 2.4^{b} \\
\text { very low }\end{array}$ & $\begin{array}{l}3.1 \pm 0.1^{\mathrm{b}} \\
\text { very low }\end{array}$ & $F=13.61 P=0.000$ \\
\hline $\mathrm{Zn}$ & $\begin{array}{l}79.5 \pm 27.1^{\mathrm{a}} \\
\text { moderate }\end{array}$ & $\begin{array}{c}47.5 \pm 6.1^{\mathrm{b}} \\
\text { low }\end{array}$ & $\begin{array}{c}33.6 \pm 2.4^{\mathrm{b}} \\
\text { very low }\end{array}$ & $F=13.02 P=0.000$ \\
\hline
\end{tabular}


585 Table 4. Physiological parameters in the lichen Flavoparmelia caperata as a function of distance from the landfill: chlorophyll integrity (OD $435 / 415)$, potential quantum yield of PSII as indicator of photosynthetic efficiency $\left(\mathrm{F}_{\mathrm{v}} / \mathrm{F}_{\mathrm{M}}\right)$, dehydrogenase activity as indicator of lichen viability $\left(\mathrm{A}_{492} / \mathrm{g}\right.$ dw), TBARS, thiobarbituric acid reactive substances ( $\mu \mathrm{mol} / \mathrm{g} \mathrm{dw})$, ergosterol content $(\mathrm{mg} / \mathrm{g} \mathrm{dw})$, caperatic and usnic acid (\% dw). Significant differences between sites $(P<0.05)$ are indicated by a different letter.

590

\begin{tabular}{lcccc}
\hline Parameters & landfill & $\mathbf{2 0 0} \mathbf{~ m}$ & $\mathbf{1 5 0 0} \mathbf{~ m}$ & ANOVA \\
\hline $\mathrm{OD}_{435 / 415}$ & $0.95 \pm 0.02^{\mathrm{a}}$ & $1.02 \pm 0.04^{\mathrm{b}}$ & $1.07 \pm 0.03^{\mathrm{b}}$ & $F=25.68 P=0.000$ \\
$\mathrm{~F}_{\mathrm{v}} / \mathrm{F}_{\mathrm{M}}$ & $0.68 \pm 0.10$ & $0.73 \pm 0.04$ & $0.76 \pm 0.02$ & $F=2.026 P=0.161$
\end{tabular}




\begin{tabular}{lcccc} 
Dehydrogenase & $7.9 \pm 3.4^{\mathrm{a}}$ & $5.3 \pm 1.3^{\mathrm{b}}$ & $4.1 \pm 1.6^{\mathrm{b}}$ & $F=3.79 P=0.042$ \\
TBARS & $19.8 \pm 4.6^{\mathrm{a}}$ & $14.7 \pm 3.5^{\mathrm{a}}$ & $7.3 \pm 1.4^{\mathrm{b}}$ & $F=12.41 P=0.000$ \\
ergosterol & $0.39 \pm 0.09^{\mathrm{a}}$ & $0.43 \pm 0.05^{\mathrm{a}}$ & $0.64 \pm 0.11^{\mathrm{b}}$ & $F=8.639 P=0.007$ \\
caperatic acid $(\% \mathrm{dw})$ & $4.7 \pm 3.2^{\mathrm{a}}$ & $7.7 \pm 0.9^{\mathrm{ab}}$ & $8.6 \pm 0.8^{\mathrm{b}}$ & $F=3.74 P=0.048$ \\
usnic acid $(\% \mathrm{dw})$ & $1.37 \pm 0.14^{\mathrm{a}}$ & $1.07 \pm 0.31^{\mathrm{c}}$ & $1.19 \pm 0.31^{\mathrm{ab}}$ & $F=10.08 P=0.003$ \\
\hline
\end{tabular}


Table 5. Spearman correlation coefficients between the investigated parameters: Index of Lichen Diversity (ILD), trace elements (Cr, Fe, Ni, Cu, $\mathrm{Zn}$, $\mathrm{As}, \mathrm{Cd}, \mathrm{Pb})$, chlorophyll integrity $\left(\mathrm{OD}_{435 / 415}\right)$, thiobarbituric acid reactive substances (TBARS), dehydrogenase activity, caperatic and usnic acid, ergosterol content, potential quantum yield of PSII $\left(\mathrm{F}_{\mathrm{v}} / \mathrm{F}_{\mathrm{M}}\right)$.

595

\begin{tabular}{|c|c|c|c|c|c|c|c|c|c|c|c|c|c|c|c|}
\hline & ILD & $\mathrm{Cr}$ & $\mathbf{F e}$ & $\mathbf{N i}$ & $\mathbf{C u}$ & Zn & As & Cd & $\mathbf{P b}$ & $\mathbf{O D}_{435 / 415}$ & TBARS & $\begin{array}{c}\text { Dehydro- } \\
\text { genase }\end{array}$ & $\begin{array}{c}\text { Caperatic } \\
\text { acid } \\
\end{array}$ & $\begin{array}{c}\text { Usnic } \\
\text { acid }\end{array}$ & $\begin{array}{l}\text { Ergo- } \\
\text { sterol } \\
\end{array}$ \\
\hline ILD & - & & & & & & & & & & & & & & \\
\hline $\mathrm{Cr}$ & $-0.76 * * *$ & - & & & & & & & & & & & & & \\
\hline $\mathbf{F e}$ & $-0.78 * * *$ & $0.99 * * *$ & - & & & & & & & & & & & & \\
\hline $\mathbf{N i}$ & $-0.53^{*}$ & $0.56^{*}$ & $0.66 * *$ & - & & & & & & & & & & & \\
\hline $\mathbf{C u}$ & $-0.75^{* * *}$ & $0.99 * * *$ & $0.99 * * *$ & $0.53 *$ & - & & & & & & & & & & \\
\hline $\mathbf{Z n}$ & $-0.75 * * *$ & $0.92 * * *$ & $0.93 * * *$ & n.s. & $0.95 * * *$ & - & & & & & & & & & \\
\hline As & $-0.75 * * *$ & $1.00 * * *$ & $0.99 * * *$ & $0.54 *$ & $1.00 * * *$ & $0.93 * * *$ & - & & & & & & & & \\
\hline Cd & $-0.74 * * *$ & $0.89 * * *$ & $0.90 * * *$ & $0.69 * *$ & $0.87 * * *$ & $0.75 * * *$ & $0.88 * * *$ & - & & & & & & & \\
\hline $\mathbf{P b}$ & $-0.91 * * *$ & $0.87 * * *$ & $0.90 * * *$ & $0.61 *$ & $0.86^{* * *}$ & $0.90 * * *$ & $0.86^{* * *}$ & $0.81 * * *$ & - & & & & & & \\
\hline $\mathbf{O D}_{435 / 415}$ & $0.61 *$ & $-0.68 * *$ & $-0.68 * *$ & n.s. & $-0.70 * * *$ & $-0.78 * * *$ & $-0.68 * *$ & $-0.55^{*}$ & $-0.78 * * *$ & - & & & & & \\
\hline TBARS & $-0.51^{*}$ & $0.76 * * *$ & $0.73 * * *$ & n.s. & $0.76 * * *$ & $0.69 * *$ & $0.76 * * *$ & $0.67 * *$ & $0.58 * *$ & n.s. & - & & & & \\
\hline Dehydrogenase & n.s. & n.s. & $0.52 *$ & n.s. & n.s. & $0.53 *$ & $0.50^{*}$ & $0.54 *$ & $0.54^{*}$ & n.s. & n.s. & - & & & \\
\hline Caperatic acid & $0.54 *$ & n.s. & $-0.51^{*}$ & n.s. & n.s. & $-0.57 *$ & $-0.51^{*}$ & $-0.56^{*}$ & $-0.65^{*}$ & $0.74 * *$ & n.s. & $-0.77 * *$ & - & & \\
\hline Usnic acid & $0.63 *$ & $-0.82 * * *$ & $-0.81 * * *$ & $-0.73 * *$ & $-0.81 * * *$ & $-0.72 * *$ & $-0.81 * * *$ & $-0.79 * * *$ & $-0.64 *$ & $0.63^{*}$ & $-0.66^{* *}$ & n.s. & n.s. & - & \\
\hline Ergosterol & n.s. & n.s. & n.s. & n.s. & n.s. & n.s. & n.s. & n.s. & n.s. & $0.63 *$ & n.s. & n.s. & n.s. & n.s. & - \\
\hline $\mathbf{F}_{\mathrm{v}} / \mathbf{F}_{\mathrm{M}}$ & n.s. & n.s. & n.s. & n.s. & n.s. & n.s. & n.s. & n.s. & n.s. & n.s. & n.s. & n.s. & n.s. & n.s. & n.s. \\
\hline
\end{tabular}

